\title{
DU KAN IKKE TALE OM DAS BECKWERK; DU ER ALLEREDE I DAS BECKWERK
}

\begin{abstract}
YOU CAN'T TALK ABOUT DAS BECKWERK; YOU ARE ALREADY IN DAS BECK-
WERK I Subjected to a one-year ban on performances in the public spaces of Scandinavia, the former CEO of the Copenhagen-based enterprise Das Beckwerk held a lecture on gth December zoll solely for the ears of the rising star of fictionality and narratology Richard Walsh from the University of York. The lecture dealt not only with the disappearing boundaries between reality and fiction but also with how novel characters have become legal citizens, while the author is turned into fiction. Finally the former CEO dismisses the judgment in the famous trial

"Thomas Skade-Rasmussen Strøbech versus Gyldendal and Helge Bille Nielsen". He calls it unjust and a neglect of the fictional character's right to a personal name, story and picture.
\end{abstract}

For your ears only!

Den 9. december 2oII holdt den forhenværende leder af virksomheden Das Beckwerk følgende foredrag alene for "the Godfather of Fictionality", den engelske litteraturteoretiker Richard Walsh i et auditorium på Aarhus Universitet som del af seminaret "Challenging Fiction". De øvrige tilstedeværende i auditoriet havde alle fået udleveret ørepropper og kunne kun se foredraget, men intet høre. Den dengang stadig navnløse forhenværende virksomhedsleder var efter lukningen af Das Beckwerk blevet underlagt en et-årig karantæne fra ytringer i det offentlige rum i Skandinavien og kunne derfor ikke tale til de tilstedeværende skandinaver, men udelukkende til englænderen Richard Walsh.

Forelæsningen undersøger den forsvindende grænse mellem virkelighed og fiktion; samt viser, hvordan romanpersoner er blevet legale borgere, mens forfatteren er blevet en fiktion.

\section{Du kan ikke tale om Das Beckwerk; du er allerede $i$ Das Beckwerk}

Den navnlose krop og forhenvarende leder af virksombeden Das Beckwerk ankommer til seminaret og indtager talerstolen ifort sorte jeans, sort rullekravesweater, sorte sko og en hvid paryk, bvilket (for alle de, der ikke kender til Das Beckwerk) fär ham til at ligne Andy Warbol. 
I ... det øjeblik, jeg sagde "I”, blev De og jeg, hr. Walsh, og sågar alle de ikke-lyttende her i auditoriet, dagens ikke-publikum, forvandlet til et beckwerk, et værk i det altomfattende Das Beckwerk, en virksomhed eller en organisation, som ikke længere eksisterer.

I året 200I - i dagene omkring II. september - blev den danske statsborger, forfatter, kunstner, musiker og menneske mm. Claus Beck-Nielsen erklæret død; og kroppen, der indtil da var blevet identificeret som Claus Beck-Nielsen, blev forvandlet til et navnløst væsen.

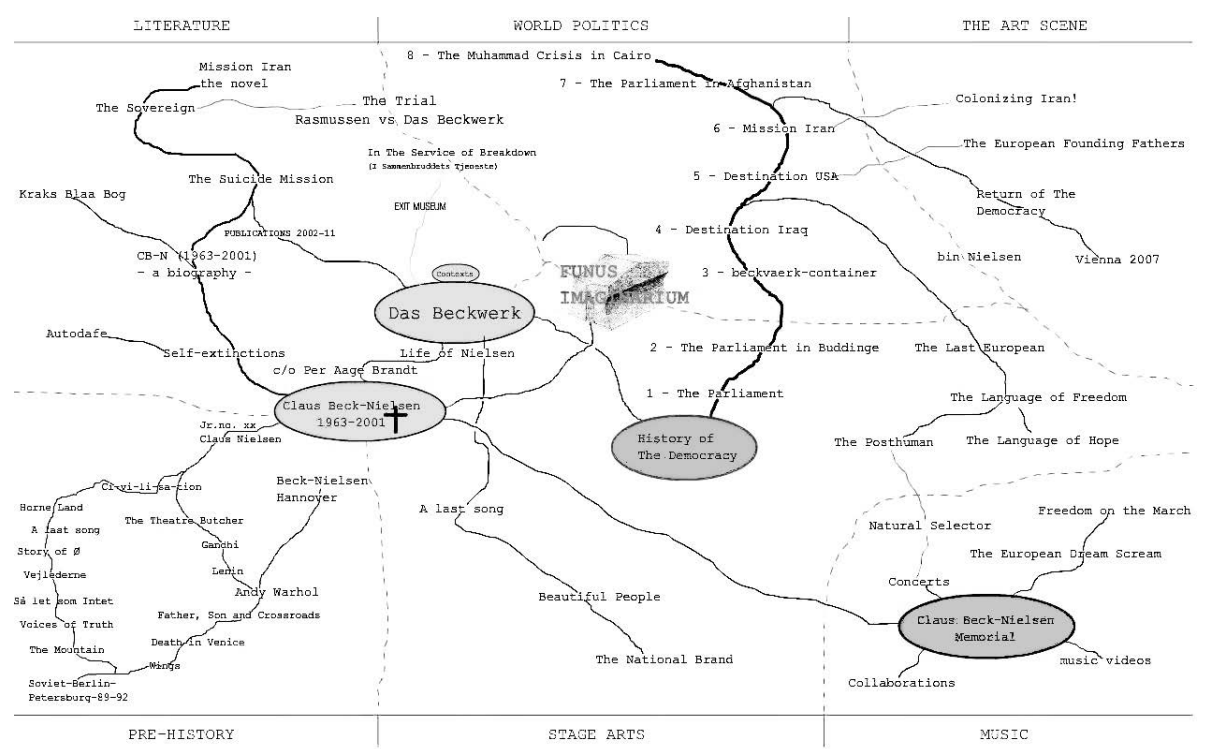

Illustration I: Beckverdenskortet, der findes på www.dasbeckwerk.com.

I 2002 blev virksomheden Das Beckwerk oprettet, og den navnløse krop blev af bestyrelsen ansat som forsøgsperson for virksomhedens eksperimenter med at skabe nye former for menneskelig væren hinsides identiteten, samt forsøg på at skabe nye aktive forbindelser mellem den enkelte verdensborger og den samtidige verdenshistorie.

Das Beckwerks produkter blev af omverdenen ofte identificeret som kulturelle produkter eller kunstværker og tog bl.a. form af vandringer, seriel fotografi, video, performance, opera, installation, revolutioner og andre former for historiske begivenheder, samt ikke mindst adskillige romaner og andre former for litterær fiktion, der involverede fortællende forfattere og/eller karakterer.

De vigtigste af disse udfordringer af fiktionsbegrebet er: Selvudslettelser fra 2002; Claus Beck-Nielsen (1963-200I) - En Biografi fra 2003; Selvmordsaktionen fra 2005; og Suvercenen fra 2008. 
Lad os undersøge, hvordan det forholder sig med forfatteren og dennes status i disse fire bøger:

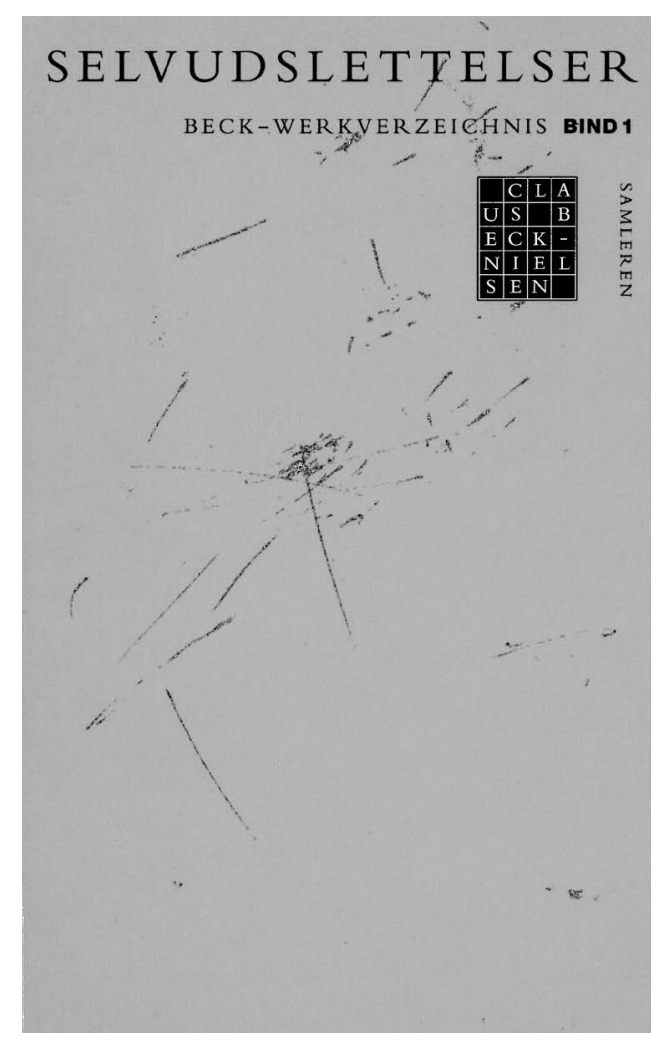

IIlustration 2: Forsiden af Selvudslettelser.

\section{Selvudslettelser (2002)}

Det fremstår klart - både på omslag og titelblad - at forfatteren af denne roman er Claus Beck-Nielsen. Men på den særlige folde-ud-plakat, der er placeret bagest i bogen, bliver forfatteren, Claus Beck-Nielsen, præsenteret som værende afdød: "(I963-200I)". At udgive en bog af en afdød forfatter er ikke usædvanligt. Det usædvanlige er, at plakaten i denne bog var det første sted i verden og den første gang nogensinde, at forfatterens død blev bekendtgjort. Ikke "forfatterens død" i al almindelighed (som mange læsere fejlagtigt har ment), men blot denne individuelle forfatter, Claus Beck-Nielsens død. 


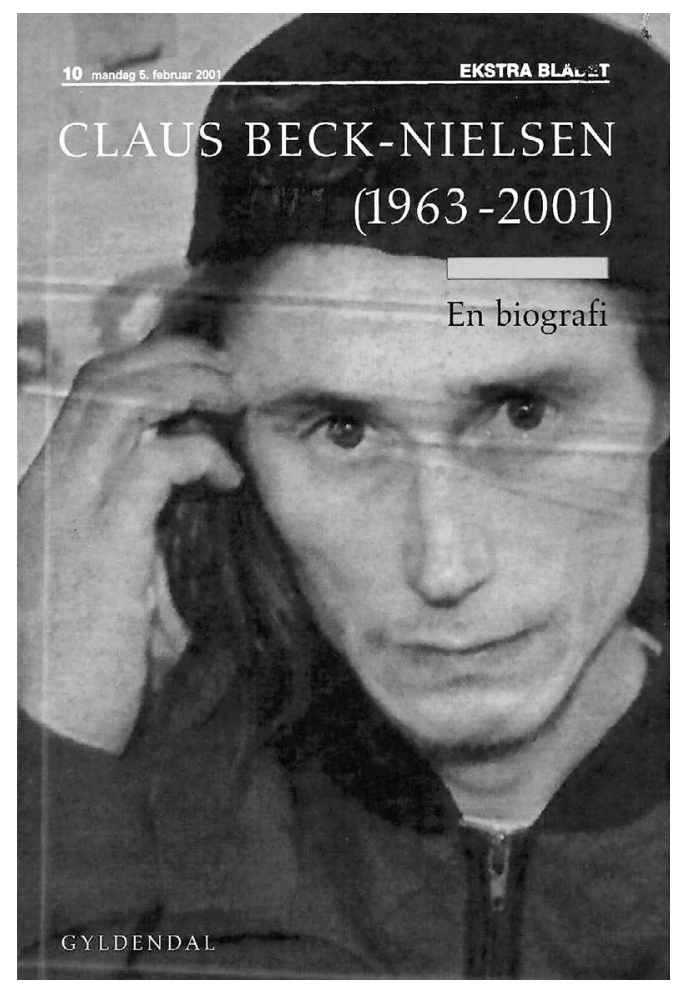

Illustration 3: Forsiden af biografien.

I 2003 udkom Claus Beck-Nielsen (I963-200I) - En Biografi. Og her bliver spørgsmålet om forfatterens status endnu mere kompliceret: Hvem er forfatteren til denne bog? Ser man på bogen, kan man ikke med sikkerhed sige, om forfatteren er Claus Beck-Nielsen og titlen (1963-200I), eller om titlen er Claus Beck-Nielsen (1963-200I), og bogen dermed en biografi uden (navngiven) forfatter.

Hvad angår Selvmordsaktionen (2005), så har vi her en navngiven forfatter, men det er hverken en eksisterende borger i nogen stat, en statsløs eller bare et pseudonym for en af disse, men derimod en URL, en adresse på internettet. 


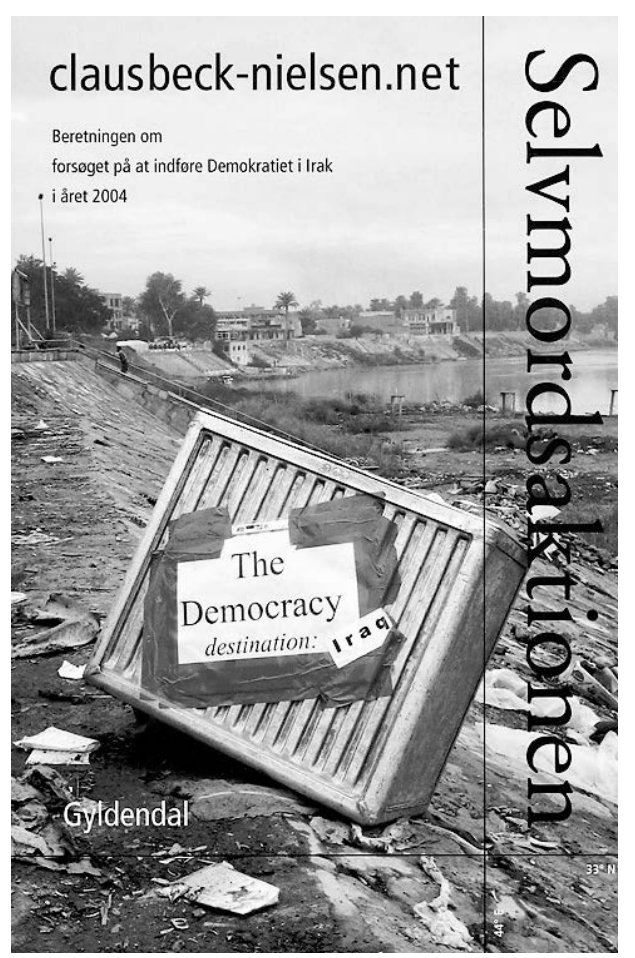

Illustration 4: forsiden af Selvmordsaktionen.

Og i tilfældet Suvercnen (2008) er forfatteren virksomheden Das Beckwerk, som også er underskriveren af kontrakten med udgiveren Gyldendal, samt indehaveren af ophavsrettighederne til værket.

I løbet af Beckwerk-æraen er der sket en fiktionalisering af forfatteren. Og det gælder ikke kun de litterære værker. I alle de forskellige former for værker og produkter, som Das Beckwerk afstedkom i årene 2002-II, blev det stadig sværere at identificere forfatteren, afsenderen, fortælleren, kunstneren, personen og sågar kroppen, der talte, skrev, optrådte eller "stod bag".

Jeg sætter ikke spørgsmålstegn ved, hvorvidt der overhovedet er en krop, en (slags) menneskeligt væsen, der taler til Dem i dette nu, hr. Walsh. Jeg påstår ikke, at virkeligheden ikke findes, og at sproget er det eneste virkelige, jeg postulerer heller ikke "forfatterens død” i al almindelighed. Og jeg forsøger ikke at sætte spørgsmålstegn ved, hvorvidt en eller flere menneskelige kroppe har været involveret i skrivningen eller skabelsen af de fire nævnte litterære fiktionsværker. Jeg hævder blot, at forfatteren til disse fire værker selv er blevet en del af fiktionen. 
Som bevis på min påstand vil jeg præsentere Suvercenen:

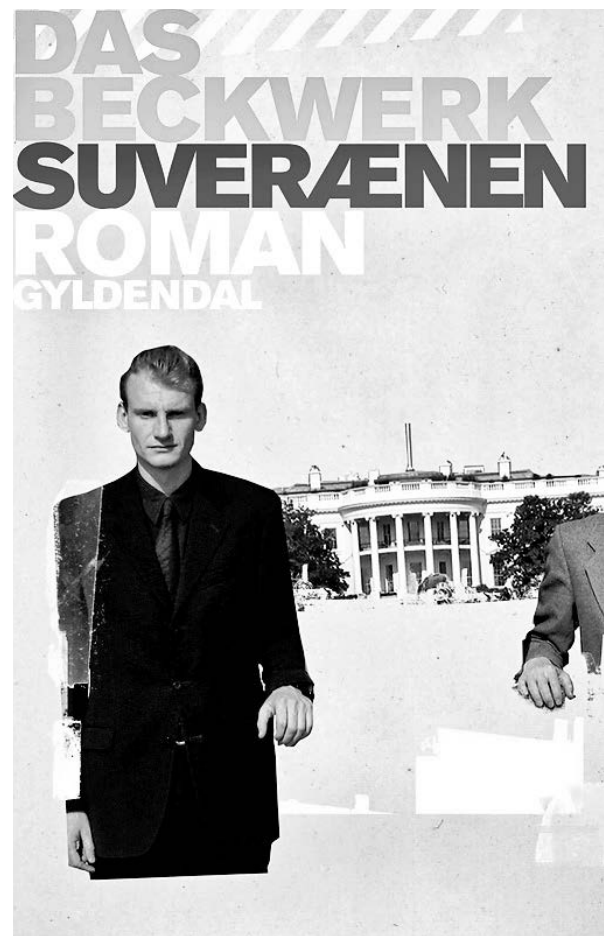

Illustration 5: forsiden af Suveraenen.

Ved første øjekast lader Suverønen til at være en klassisk og endda temmelig ukompliceret roman: På omslaget præsenterer den sig som "roman” med en titel og en navngiven forfatter. Og begynder man at læse, glider man ubesværet ind $\mathrm{i}$ en ligefrem historie fortalt af en "karakter" eller romanperson ved navn Nielsen og med en hovedperson ved navn Thomas Skade-Rasmussen Strøbech, eller bare Rasmussen. MEN den fortællende romankarakter Nielsen blev af de fleste læsere opfattet som værende identisk med forfatteren. MEN ikke den på omslaget navngivne forfatter, virksomheden Das Beckwerk. Og romanens hovedperson, den tilsyneladende helt fiktive Thomas Skade-Rasmussen Strøbech - som på side 27 bliver transformeret til slet og ret at være Rasmussen - sagsøgte få måneder efter romanens udgivelse forfatteren for (blandt andet): krænkelse af individuelle personers ret til eget navn, egen historie og eget billede. MEN hvem i alverden var så den sagsøgte forfatter? Ifølge bogen selv og kontrakten, der havde ført til udgivelsen, var og er Das Beckwerk forfatteren. MEN nej: Den fiktive hovedperson og hans advokat sagsøgte Claus Beck-Nielsen. MEN som vi allerede ved, så var Claus Beck-Nielsen blevet erklæret død allerede seks år før tilbage i 2002. På en folde-ud-plakat bagest i et fiktionsværk, ja, MEN også i den såkaldte eller tilsyneladende retslige virkelighed: Siden i hvert fald 2003 eller 2004 har der ikke eksisteret nogen legal borger ved 
navn Claus Beck-Nielsen i Danmark eller i nogen anden stat på planeten Jorden. Og da det danske retssystem kun accepterer retssager og søgsmål mod "virkelige" eksisterende identiteter - individer så vel som virksomheder, organisationer og stater - så var den fiktive romanperson og hans advokat i sidste ende nødt til at stævne en sådan reelt eksisterende identitet. Og derfor valgte de at sagsøge Helge Bille Nielsen.

Hvem er Helge Bille Nielsen? Tja, man kan sige, at Helge Bille Nielsen er en fiktiv person, som af den danske stat er blevet identificeret som en legal borger.

Efter igennem to år forgæves at have forsøgt at få den danske stat til at acceptere den navnløse krop som en legal navnløs borger var Das Beckwerk i 2004 nødt til at opgive. Virksomhedens bestyrelse gav den navnløse krop et såkaldt dæknavn til at dække sin manglende identitet med. Man valgte et næsten tilfældigt navn: På navneskiltet, der var opsat på døren til den lejlighed, som den navnløse krop i efteråret 2002 flyttede ind i, stod der "Helge Bille". Den "virkelige" og legale borger Helge Bille havde sat skiltet op i 1929 og levet bag det indtil sin død i I986. Helge Bille havde været en virkelig person i virkeligheden, men var det ikke længere.

Den danske stat accepterede dæknavnet, ikke som dæknavn, men derimod som den navnløse krops helt legale navn. Og følgelig skulle den navnløse krop også have forskellige dokumenter, der identificerede ham eller hende, den eller det som værende den legale borger Helge Bille Nielsen: et sygesikringsbevis, et kørekort, et pas osv. På og i alle disse dokumenter bliver den navnløse krop identificeret som Helge Bille Nielsen. Den krop, som står her og taler til Dem i dette nu? Ja. Og nej. Vi vil lade dette spørgsmål eller paradoks ligge og vippe på kanten af afgrunden, lige til det næsten er slut.

Helge Bille Nielsen blev sagsøgt af hovedpersonen i Suvercnen og hans advokat. Men Helge Bille Nielsen og bestyrelsen i Das Beckwerk protesterede og hævdede, at den legale og dermed virkelige forfatter af romanen var Das Beckwerk, og at Helge Bille Nielsen kun havde medvirket i det skabende arbejde på romanen som ansat i Das Beckwerk.

Ikke desto mindre valgte Københavns Byret og det danske retssystem at acceptere søgsmålet. Og således måtte Helge Bille Nielsen i januar 2OII møde i retten som den formodede forfatter af Suvercenen. I mellemtiden var sagen på grund af sin principielle betydning blevet flyttet eller forfremmet fra Byretten til Østre Landsret.

Det første spørgsmål, som den navnløse krop (under dække af navnet Helge Bille Nielsen) blev stillet, var: Er du Helge Bille Nielsen. ”Ja”, svarede den eller det, hun eller han. Dette svar var - for de fleste af de mange tilstedeværende i retten den dag - en åbenlys løgn. Den, det, hun eller han løj for de tre dommere i Landsretten. Hverken den anklagede selv eller de fleste andre af de tilstedeværende i retten den dag havde nogensinde tænkt på eller omtalt og dermed identificeret ham, hende, den eller det som Helge Bille Nielsen. Men måske havde anklagede intet andet valg 
end at lyve. At sige sandheden og svare "nej, jeg er ikke Helge Bille Nielsen" ville have medført et øjeblikkeligt sammenbrud af den institutionaliserede fiktion, vi alle bebor og kalder "virkeligheden".

Efter denne indledende løgn spurgte dommeren Helge Bille Nielsen, om han var klar over, at han var forpligtet til at sige sandheden, kun sandheden og intet andet end sandheden. Og fiktionen Helge Bille Nielsen svarede "ja”.

Hovedpersonens advokat hævdede derpå, at Helge Bille Nielsen var den virkelige og legale forfatter af Suvercenen, og det lod til, at hovedparten af de tilstedeværende i Landsretten den dag - måske lige bortset fra fiktionen Helge Bille Nielsen selv var enige i denne påstand og det på trods af, at der hverken var eller er nogen, der kan bevidne det: Intet menneske på planeten Jorden har (med egne øjne) set nogen skrive Suvercnen.

Men - måske på grund af det voldsomme pres fra konsensus - gav Helge Bille Nielsen efter og indrømmede, at ”jeg har skrevet måske 97 eller 98 procent af omtalte roman."

Lad os, i det mindste De og jeg, hr. Walsh, acceptere denne fiktion som værende virkeligheden. Tillad mig for en kort stund at tale til Dem som Helge Bille Nielsen: - Ja, siger jeg, - jeg er den virkelige forfatter af Suvercenen. Jeg er blevet sagsøgt og bragt for retten af hovedpersonen i min roman. Da bogen er en roman, et litterært fiktionsværk, så er dens hovedperson Thomas Skade-Rasmussen Strøbech selvfølgelig et produkt af min litterære fantasi eller imaginationskraft. Jeg er hans skaber.

Det er ikke blot en absurd påstand fra min side: Det er stadfæstet af den danske Landsret og dermed en legal sandhed. I Landsrettens dom af I7. marts 20 II accepterer de tre dommere Suvercnen som en roman, et litterært fiktionsværk, og deraf følger, at jeg, Helge Bille Nielsen, blev frikendt for modpartens anklage om "identitetstyveri” og anklagerne om krænkelse af den personlige ret til eget navn, egen historie og eget billede etc.

"Roman” står der skrevet på forsiden af Suvercenen, akkurat som der gør på forsiden af bestselleren Min kamp af den norske forfatter Karl Ove Knausgård. Deraf følger, at Thomas Skade-Rasmussen Strøbech er del af en fiktion, akkurat som Knausgårds onkel Gunnar i Min kamp. Det danske retssystem havde altså på den ene side accepteret et søgsmål fra en fiktiv person, som var han en virkelig person. Men på den anden side nægtede man ham altså de basale menneskerettigheder, den ret til eget navn, egen historie og eget billede, som normalt gælder for virkelige personer.

Den retssal, som engang var stedet, hvor virkeligheden blev stadfæstet, hvor individer, firmaer, handlinger osv. blev identificeret som værende enten legale eller illegale, virkelige eller falske, og hvor grænsen blev trukket mellem virkelighedens og fiktionernes verden, er nu blevet paradoksernes arena. 
Dette er selvfølgelig blot et symptom: Sandheden er, at grænsen mellem virkelighed og fiktion, mellem legale borgere og fiktive personer ikke længere eksisterer.

Hvornår forsvandt denne grænse? Det er nok svært at sætte en præcis dato for denne begivenhed. Men herfra, hvor jeg står, ser det ud, som om det skete omkring II. september 200I, altså omkring Claus Beck-Nielsens død og Das Beckwerks kommen til verden. Siden da er der ikke længere nogen grænser i verden og det værende. Ikke engang mellemrummene findes længere. Der er kun et endeløst, kontinuerligt rum af uafbrudt forvandling. Væren - fiktiv såvel som virkelig - er nu en uafbrudt overgang. "At være og ikke at være” er svaret på det spørgsmål, som en af Historiens berømteste karakter engang for mere end fem hundrede år siden stillede.

Som Suvercenen og retssagen omkring den har vist os, så er personer i romaner og andre former for litterær fiktion ikke mindre virkelige end deres forfattere; og forfatterne er ikke mindre fiktive end deres hovedpersoner.

Den retslige konsekvens af dette burde selvfølgelig være, at romanpersoner skal have de samme borger- og menneskerettigheder som deres forfattere - stemmeret, retten til statsborgerskab, ytringsfrihed, juridiske rettigheder osv., og dermed selvfølgelig også retten til at sagsøge deres forfattere og bringe dem for retten. Efter min mening var Landsrettens beslutning og dom - at frikende Helge Bille Nielsen fra alle anklager - forkert. Med denne dom stadfæster man, at Helge Bille Nielsen og forlaget Gyldendal (og følgelig også enhver anden forfatter og ethvert andet forlag) ved at skrive "roman” på forsiden af en bog gør sig immune over for enhver anklage om identitetstyveri og krænkelse af retten til eget navn, egen historie osv. Med sin dom forsøger det danske retssystem kort sagt at opretholde den grænse mellem virkeligheden og fiktionen, som ikke længere findes.

Det eneste retfærdige ville selvfølgelig have været at idømme Helge Bille Nielsen og denne krop for eksempel et års betinget eller ubetinget fængsel. Forudsat, selvfølgelig, at denne Helge Bille Nielsen virkelig er forfatteren af Suvercnen, ja, forudsat at Helge Bille Nielsen overhovedet er en virkelig person. Og det er han ikke. Uanset hvor meget han prøver:

Den I7. januar 20II blev Das Beckwerk nedlagt af sin bestyrelse. I et forsøg på blandt meget andet - at stoppe den eskalerende udviskning af grænsen mellem virkeligheden og fiktionen. I et forsøg på at redde det sidste sted i verden, som stadig var uden for Das Beckwerk. Forgæves. Det altomfattende Das Beckwerk bliver ved med at ekspandere. Selv nu i dette øjeblik, hvor jeg står her og taler til Dem, hr. Walsh, bliver ikke blot jeg, men også De og alle de ikke-lyttende mennesker omkring os og sågar hele dette auditorium, hvor vi opholder os, forvandlet til et beckwerk, et værk i det altomfattende værk ved navn Das Beckwerk, en virksomhed, som ikke engang længere eksisterer. 
Og jeg? Hvem er jeg? De tror måske, at jeg netop nu foregiver at være "trådt i karakter" som en fiktiv person. Tværtimod. Min optræden eller performance her i dag - denne i Deres øjne formodentlig Andy-Warhol-lookalike eller Andy-Warholwannabe - er i virkeligheden et forsøg på at være den virkelige og legale Helge Bille Nielsen, som det danske retssystem, den danske stat og ikke mindst det pas, som denne stat har givet mig, påstår, at jeg - alias den her talende krop - er.

Her tager den talende krop et pas frem af sin bukselomme og viser det til hr. Walsh.

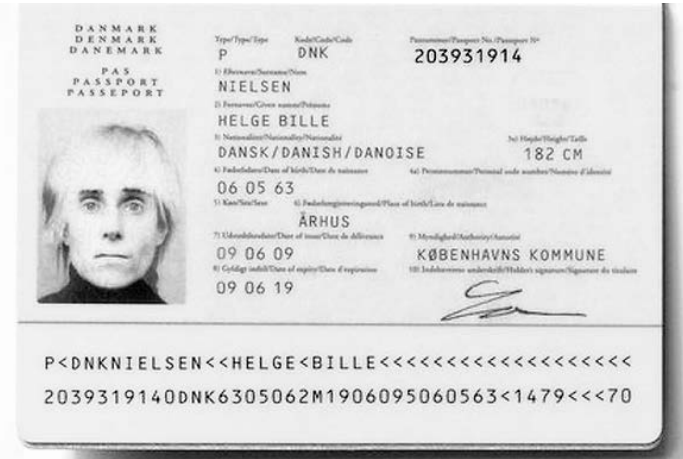

Illustration 6: opslaget i passet, hvor billede, navn, personnummer etc. kan ses.

Som De måske kan se, er det billede, som skal forbinde navnet Helge Bille Nielsen med en virkeligt eksisterende krop, et fotografi taget af den amerikanske fotograf Robert Mapplethorpe i 1986 (selvsamme år hvor den "virkelige” Helge Bille døde sin uigenkaldeligt virkelige død!). Ind i dette billede har man diskret "blended" nogle få træk fra det ansigt, som den her talende krop har, når den ikke - som nu - forsøger at ligne Helge Bille Nielsen.

Dette er ingen leg, hr. Walsh, intet spil. Det er på tragisk vis alvor. Og hvad Sandheden angår: Jeg er bange for, at Das Beckwerk og dermed jeg og hele dette auditorium og alle kroppene og begivenhederne, der i denne stund finder sted i det, uigenkaldeligt er hinsides sandhed og løgn; jenseits Wahrheit und Betrug.

Jeg taler ikke "under-cover" som en litterær fiktion. Det er den legale forfatter til Suvercenen, der taler til Dem, hr. Walsh. Men, som vi har set, er så vel forfatteren som hans hovedperson og karakteren, som fortæller hovedpersonen, alle fiktioner. Det eneste virkelige er bogen, jeg holder i min hånd.

(Jeg har læst dele af Deres hovedværk The Rhethoric of Fictionality, og nu spørger jeg selvfølgelig mig selv, hvilke konsekvenser vil min optræden eller performance og de ting, jeg har fortalt her i dag, mon have for Deres teori? 
De har elimineret eller udrenset fortællerinstansen og den implicitte forfatter fra litterære fiktionsværker. Inden for det seneste halvandet årti har De, Mister Walsh, reduceret koret af forskellige fortællende stemmer i litterære fiktionsværker til de eneste to, der hele tiden har været: den virkelige forfatter og/eller en fiktiv karakter. Endelig, efter alle disse årtier med stadig flere stadig mere komplicerede teorier, er alting blevet enkelt og letforståeligt. Men som vi har set i min "sag", så er der samtidig sket det, at den fiktive karakter er blevet "legaliseret" og dermed virkelig, mens den virkelige forfatter er blevet en fiktion.

Og så er mit spørgsmål: Hvad betyder det? For os alle, ikke blot her, men i hele denne engang virkelige verden af personer, ting, grøntsager og begivenheder, og ikke mindst: Hvad er konsekvenserne for Dem, for realiteten af Dem som forfatteren, der fortæller i The Rhethoric of Fictionality? Er De, Mister Walsh, nu også bare en fiktion?)

NB: Foredraget blev selvfølgelig skrevet og holdt på engelsk, men er her gendigtet på dansk af Nielsen - www.nielsen.re 